\title{
Energizing Social Interactions at Work: An Exploration of Relationships that Generate Employee and Organizational Thriving
}

\author{
Robert M. Rosales \\ LEAD ACADEMY, Positive Leadership Consultancy, New York, NY, USA \\ Email: Robert@leadacademy.nyc
}

How to cite this paper: Rosales, R.M. (2016) Energizing Social Interactions at Work: An Exploration of Relationships that Generate Employee and Organizational Thriving. Open Journal of Social Sciences, 4, 29-33.

http://dx.doi.org/10.4236/jss.2016.49004

Received: May 16, 2016

Accepted: September 19, 2016

Published: September 22, 2016

\begin{abstract}
A company's greatest asset is its people provided they are fully engaged. In our increasingly service-based economies, social relationships and swift coordination among employees are the means by which a lot of work gets done. Thus, whether organizations and their employees flourish or languish largely depends on the quality of the social connections they nurture. The quality of the workplace connections can be defined as life giving (high quality) or life depleting (low quality). Positive social interactions facilitate organizational learning, cooperation, effectiveness, and employee loyalty, among many other desirable outcomes. High-quality connections are brief, mutually beneficial, and dynamic dyadic interactions, which have the power to energize people with vital resources to do their work well. Positive psychology and positive organizational scholarship - the science of how people and organizations flourish-provides us with tools that can help bring about high-quality connections. This paper defines high-quality connections at work, examines the benefits of highquality connections, and provides a framework for building high-quality connections. The paper shows that high-quality connections are a pathway to build individual and organizational flourishing.
\end{abstract}

\section{Keywords}

Relationships at Work, High-Quality Connections, Positive Psychology, Positive Organizational Scholarship

\section{Introduction}

Aristotle famously declared that man was a social animal. As Csikszentmihalyi [1] put, "We are biologically programmed to find other human beings the most important ob- 
jects in the world" (p. 164). Our biological bodies are hardwired for close relationships and the capacity to love and be loved is intrinsically human [2]. Consequently, we don't want to be alone, or rejected, and take measures to avoid these experiences [3]. Instead, we want to belong, to have social relationships, and to fit in. Our urge to connect with other people is a superpower that keeps us close to others [4].

At work too, other people matter most. As most adults spend a significant amount of time interacting with other individuals at work, the workplace is an important contributor to individual well-being, particularly because it offers the potential for mutually beneficial relationships [5]. Indeed, research shows that relationships and work are among the major contributors to individual well-being [6] and positive psychology identifies relationships as one of the major pathways for human flourishing [7]. Thus, it could be argued that the ultimate competitive advantage for a knowledge-based organization in today's information age is its people and that only people, in the right context, can make good organizations great, in large part through their positive, highquality relationships, provided they are engaged.

\section{Importance of Relationships at Work}

A recent U.S. survey highlighted that the top engagement condition for 79 percent of respondents was their relationship with co-workers [8]. According to Ragins and Dutton [9] relationships and swift coordination are the means by which work is done and meaning is found in organizations. For Stephens, Heaphy, and Dutton [10], the importance of connections in the workplace rests on four assumptions:

1) Humans are intrinsically social and have a need to belong, which makes connections an essential part of their social experience in organizations.

2) Connections are dynamic and depend on how people feel, think, and behave while interacting with others.

3) Organizations perform their work through social processes; therefore connections are key elements in the accomplishment of work.

4) Connections vary in quality. Differences in quality reflect how healthy and wellfunctioning the dyadic interaction is at a particular point in time.

\section{Positive Outcomes of High-Quality Connections and Relationships}

We summarize below the main findings of various studies that investigated how positive relationships and connections contribute to an organization's success [10]-[15]:

Generate feelings of vitality and aliveness, trust, support, and resiliency; Build individual commitment and engagement by providing psychosocial support, inspiration, and feedback; Transform conflict into a source of learning and personal growth, and promote perceived fairness; Enable positive emotions that promote broader thinking, adaptation to change, enhanced self-image, job satisfaction, and greater organizational citizenship; Improve individual functioning (e.g. lower physiologic responses to stress, longer life-span, lower risk of death, stronger immune system, more energy, lower an- 
xiety); Foster better learning, adaptability and creativity by facilitating engagement and self-discovery, positive emotions and trust; Increase productivity and performance by enhancing cooperation, adaptability, dynamism, and the attachment of employees, customers, and suppliers.

\section{Pathways to Forming High-Quality Connections}

I propose a model that is largely inspired by Stephens et al. [10]. This model identifies three basic pathways that, in addition to the organizational context, build and strengthen high quality connections, as follows:

\subsection{Cognitive Mechanisms}

Stephens et al. [10], describe cognitive mechanisms as conscious and unconscious mental processes that prime people to build high-quality connections:

Other-Awareness. In order to establish connection, one needs to be aware of the presence of others, who they are, and their distinct behavior as this provides some context for one's actions.

Impressions of others: The quick impressions -less than 5 minutes-we form about others can also shape how connections develop.

Perspective-taking. Perspective-taking is imagining yourself in another person's shoes, thus preparing us to show care and concern. As such, it is motivated by pro-social disposition [16].

\subsection{Emotional Mechanisms}

Emotional mechanisms are feelings that open individuals up to connection and are shared between people [9]:

Positive Emotions and Emotional Contagion: Fredrickson [17] argues that positive emotions broaden our mindset and allow us to discover and build new skills, social ties, knowledge, and behaviors. They create an upward spiral that, over time, improves odds for survival, health and fulfillment. Emotional contagion describes how a person or group influences others as they unconsciously mimic each other.

Empathy and Compassion: Empathy occurs when a person is self-aware and vicariously experiences another person's emotional state. Armstrong [18] argues that while empathy focuses on experience, compassion focuses on action in order to help another individual. Thus, compassion takes empathy one step further and is the key to addressing suffering and combating incivility in organizations.

\subsection{Behavioral Mechanisms}

For Stephens et al. [10] behavioral mechanisms are the conscious and unconscious actions that people take in response to a person, system, environment, or stimulus:

Task-enabling. Task-enabling occurs when we deliberately use strategies to help the successful performance of others, thereby energizing individuals, generating commitment, and facilitating the learning process within the organization. 
Trust. Trust is central to all positive relationships. According to Dutton [11], trusting means acting toward others in a way that your belief is conveyed in their integrity, dependability, and good motives.

Respectful Engagement. Dutton [11] argues that respectful behaviors show that we care and value another person, thereby satisfying the basic human needs for respect and dignity. With time, communicating in a supportive and positive fashion lays a foundation of trust, honesty, respect, and commitment, as a pre-condition for generating highquality connections. While criticism puts most people on the defensive, respectful engagement energizes the relationship and has an infectious effect on others [11].

\section{Conclusion}

We have defined high-quality connections as short, work-based interactions that are marked by trust, mutual regard, and active engagement and recharge people with vital resources to do their work well. As such they are one of the major pathways to build positive and thriving workplaces. Therefore, organizations would be well inspired to focus on generative processes that contribute to developing positive relationships and high-quality connections that are conducive to individual and organizational performance.

\section{References}

[1] Csikszentmihalyi, M. (1990) Flow: The Psychology of Optimal Experience. Harper \& Row, New York.

[2] Peterson, C. (2006) A Primer in Positive Psychology. Oxford University Press, New York.

[3] Haidt, J. (2006) The Happiness Hypothesis: Finding Modern Truth in Ancient Wisdom. Basic Books, New York.

[4] Lieberman, M.D. (2013) Social: Why Our Brains Are Wired to Connect. Broadway Books, New York.

[5] Diener, E. and Seligman, M.E.P. (2002) Very Happy People. Psychological Science, 13, 8083. http://dx.doi.org/10.1111/1467-9280.00415

[6] Diener, E. and Biswas-Diener, R. (2008) Happiness: Unlocking the Mysteries of Psychological Wealth. Blackwell, Oxford. http://dx.doi.org/10.1002/9781444305159

[7] Seligman, M.E.P. (2011) Flourish: A Visionary New Understanding of Happiness and Well-Being. Free Press, New York.

[8] SHRM (2015) Employee Job Satisfaction and Engagement. http://www.shrm.org/Research/SurveyFindings/Documents/2015-Job-Satisfaction-and-Eng agement-Report-Executive-Summary.pdf

[9] Ragins, B.R. and Dutton, J.E. (2007) Positive Relationships at Work: An Introduction and Invitation. In: Dutton, J.E. and Ragins, B.R., Eds., Exploring Positive Relationships at Work: Building a Theoretical and Research Foundation, Lawrence Erlbaum Associates, Mahwah, 29-45.

[10] Stephens. J.P., Heaphy, E.D. and Dutton, E.J. (2012) High-Quality Connections. In: Cameron, K. and Spreitzer, G., Eds., Handbook of Positive Organizational Scholarship, Oxford University Press, New York, 385-399.

[11] Dutton, J.E. (2003) Energize Your Workplace: How to Create and Sustain High-Quality 
Connections at Work. Jossey-Bass, San Francisco.

[12] Dutton, J.E. and Heaphy, E.D. (2006) The Power of High-Quality Connections. In: Cameron, K.S., Dutton, J.E. and Quinn, R.E., Eds., Positive Organizational Scholarship: Foundations of a New Discipline, Berrett-Koehler, San Francisco, 263-278.

[13] Reis, H.T. and Gable, S.L. (2003) Toward a Positive Psychology of Relationships. In: Keyes, C.L. and Haidt, J., Eds., Flourishing. The Positive Person and the Good Life. American Psychological Association, Washington DC, 129-159. http://dx.doi.org/10.1037/10594-006

[14] Berscheid, E. (2003) The Human's Greatest Strength: Other Humans. In: Aspinwall, L.G. and Staudinger, U.M., Eds., A Psychology of Human Strengths, American Psychological Association, Washington DC, 37-48.

[15] Diener, E. and Seligman, M.E.P. (2004) Beyond Money: Toward an Economy of Well-Being. Psychological Science in the Public Interest, 5, 1-31. http://dx.doi.org/10.1111/j.0963-7214.2004.00501001.x

[16] Grant, A.M. and Berry, J.W. (2011) The Necessity of Others Is the Mother of Invention: Intrinsic and Prosocial Motivations, Perspective-Taking, and Creativity. Academy of Management Journal, 54, 73-96. http://dx.doi.org/10.5465/amj.2011.59215085

[17] Fredrickson, B.L. (2009) Positivity: Groundbreaking Research Reveals How to Embrace the Hidden Strength of Positive Emotions, Overcome Negativity, and Thrive. Random House, New York.

[18] Armstrong, K. (2011) Twelve Steps to a Compassionate Life. Random House, New York.

\section{Submit or recommend next manuscript to SCIRP and we will provide best service for you:}

Accepting pre-submission inquiries through Email, Facebook, LinkedIn, Twitter, etc. A wide selection of journals (inclusive of 9 subjects, more than 200 journals)

Providing 24-hour high-quality service

User-friendly online submission system

Fair and swift peer-review system

Efficient typesetting and proofreading procedure

Display of the result of downloads and visits, as well as the number of cited articles

Maximum dissemination of your research work

Submit your manuscript at: http://papersubmission.scirp.org/ 